\title{
Ocular toxicity and Hydroxychloroquine: A Rapid Meta-Analysis
}

\author{
Matthew Michelson, ${ }^{\text {ab }}$ Tiffany Chow, ${ }^{a}$ Neil Martin,,${ }^{c}$ Mike Ross, ${ }^{a}$ Amelia Tee, ${ }^{\text {a }}$ Steven Minton ${ }^{b}$ \\ aEvid Science, El Segundo, CA USA \\ bInferLink, El Segundo, CA USA \\ cPacific Neuroscience Institute, Providence St John's Health Center, Santa Monica
}

\begin{abstract}
:
Rapid access to evidence is crucial in times of evolving clinical crisis. To that end, we propose a novel mechanism to answer clinical queries: Rapid Meta-Analysis (RMA). Unlike traditional meta-analysis, RMA balances quick time-to-production with reasonable data quality assurances, leveraging Artificial Intelligence to strike this balance. This article presents an example RMA to a currently relevant clinical question: Is ocular toxicity and vision compromise a side effect with hydroxychloroquine therapy?
\end{abstract}

As of this writing, hydroxychloroquine is a leading candidate in the treatment of COVID-19. By combining Al with human analysis, our RMA identified 11 studies looking at ocular toxicity as a side effect and estimated the incidence to be $3.4 \%$ (95\% Cl: $1.11-9.96 \%)$. The heterogeneity across the individual study findings was high, and interpretation of the result should take this into account. Importantly, this RMA, from search to screen to analysis, took less than 30 minutes to produce. 
medRxiv preprint doi: https://doi.org/10.1101/2020.04.28.20083378; this version posted May 12, 2020. The copyright holder for this preprint (which was not certified by peer review) is the author/funder, who has granted medRxiv a license to display the preprint in perpetuity. It is made available under a CC-BY-NC-ND 4.0 International license .

\section{Introduction:}

The COVID-19 pandemic caused by the Severe Acute Respiratory Syndrome Coronavirus 2 (SARS-Cov-2) presents clinicians and regulators with multiple challenges, including access to timely and crucial information. To mitigate this issue, many segments of the healthcare industry have looked to Artificial Intelligence (AI) for support.

The capacity of Al to aggregate and process massive volumes of information is emerging as particularly crucial in the current moment, especially as so much data is available it can be overwhelming for humans to evaluate. ${ }^{1} \mathrm{Al}$ technology, such as that from Evid Science ${ }^{\mathrm{a}}$ can unburden some of this overload by automatically processing the written text of medical papers, turning the text into a more consumable, structured set of data that can be easily searched and analyzed. Essentially, the Al turns all of the written articles into spreadsheets of results.

Meta-analysis and Systematic Literature Review are the gold standards for evidence, ${ }^{3}$ but they take significant time and effort to produce (often as long as a year ${ }^{4}$ ) and are therefore rarely updated. ${ }^{5,6}$

To produce results in a more timely manner, in this paper we propose the Rapid Meta-Analysis (RMA). An RMA follows the same general framework methodology of a Meta-Analysis, but leverages technology at every step, yielding a much faster time-to-production. Some data quality may be compromised due to the emphasis on fast time-to-production, but the ability to generate answers so quickly may warrant this trade off.

This article introduces RMA by way of practical example. Hydroxychloroquine (HCQ) has been available since the $1950 \mathrm{~s}^{2}$ and has been used to treat malaria, lupus erythematosus, and rheumatoid arthritis. Most recently, has been highlighted as a potential intervention to support patients with Covid-19. While the efficacy outcomes of hydroxychloroquine are different in each clinical condition for which it is used, adverse events tend to be consistent. In this study, we use RMA to answer a specific clinical question regarding HCQ and the degree to which ocular toxicity is a side effect. This is an important clinical question, yet the authors could not find a suitable aggregation of results.

Therefore, we leveraged the Evid Science clinical-outcomes database to produce an RMA in order to find relevant studies, screen to those focused on HCQ and vision issues, and then perform the meta-analysis computation. The data for the RMA is provided in Table 1. Based on results from 11 studies ( $\mathrm{N}=3,585)$, we expect to see major eye issues $3.4 \%$ of the time (95\% Cl: $1.11-9.96 \%)$. We note high heterogeneity across the studies ( ${ }^{2}$ is $\left.97 \%\right)$ so we caution when interpreting these results. Importantly, the entire process from search to analysis took less than 30 minutes. 
medRxiv preprint doi: https://doi.org/10.1101/2020.04.28.20083378; this version posted May 12, 2020. The copyright holder for this preprint (which was not certified by peer review) is the author/funder, who has granted medRxiv a license to display the preprint in perpetuity.

It is made available under a CC-BY-NC-ND 4.0 International license .

To be clear, a RMA, such as this, is meant to raise awareness, and should not be treated as a full Systematic Literature Review and Meta-Analysis that should strictly guide treatment. The data and results are current as of 4-11-2020.

\section{Background:}

The core innovation of an RMA is replacing as many of the steps as possible with machine intelligence, as has been proposed previously. ${ }^{7,8}$ Machines are not yet at the point where they can simply provide an answer to a posed question, so RMA instead replaces as many manual steps as possible with machine-assisted (or entirely Al) steps. The goal is that each step could eventually be replaced with Al.

To make this idea concrete, consider Figure 1 below. On the left of Figure 1, we see the standard steps (at a high level) for meta-analysis. On the right is there equivalent technology replacement.

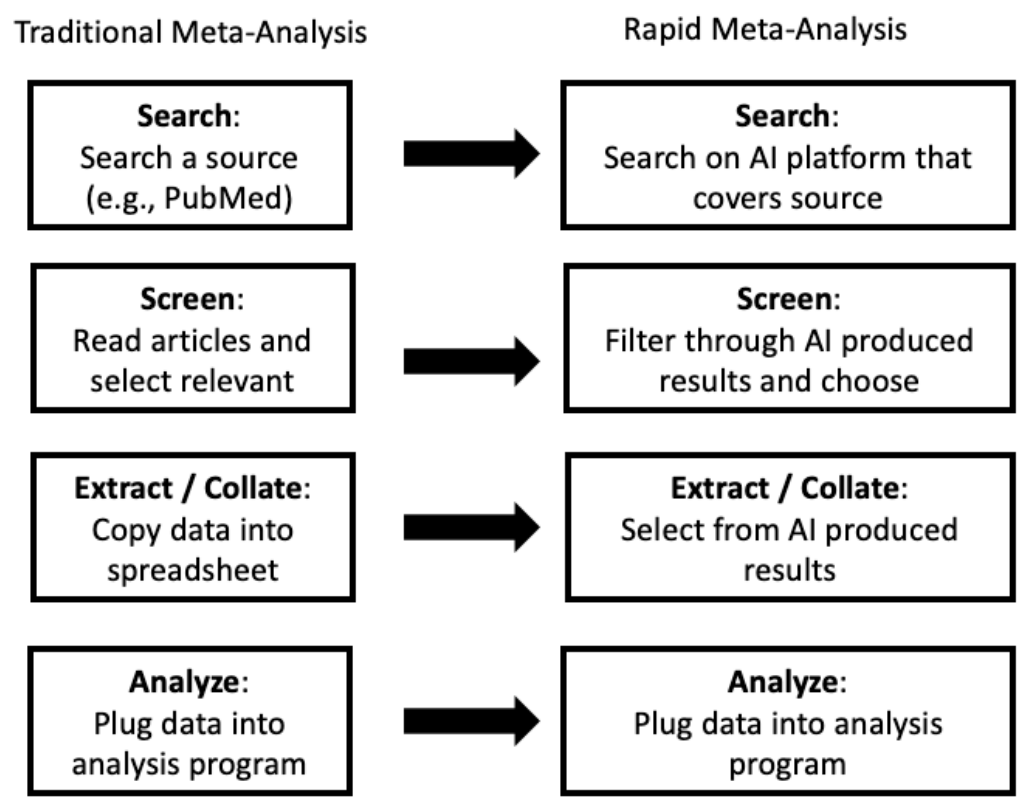

Figure 1: Traditional meta-analysis (simplified, left) vs. RMA using Al (right)

For this RMA, we leverage the Evid Science clinical-outcomes database for searching and screening (though any suitable Al system could provide similar benefit). This database was built using the Evid Science Al, which is capable of turning written text about results into a "structured" representation (e.g., a row in a database or spreadsheet).

Consider Figure 2 below. It shows a sentence about toxicity detected for a set of patients. The $\mathrm{Al}$ is able to break this sentence down into fields (such as result, intervention and outcome), automatically. It knows that 18 is a number of patients, and since that represents $30.5 \%$ of the patients, it must be 18 of 59. It also knows that the 18 was associated with "Retinal toxicity being detected", in contrast to the 5 , which is associated with "color vision impairments." 
medRxiv preprint doi: https://doi.org/10.1101/2020.04.28.20083378; this version posted May 12, 2020. The copyright holder for this preprint (which was not certified by peer review) is the author/funder, who has granted medRxiv a license to display the preprint in perpetuity. It is made available under a CC-BY-NC-ND 4.0 International license .

\section{Retinal toxicity was detected in 18 (30.5\%) of the patients, and 5 (8.5\%) developed color vision impairments.}

\begin{tabular}{|l|l|l|}
\hline Result & Intervention & Outcome \\
\hline 18 of 59 & hydroxychloroquine & Retinal toxicity was detected \\
\hline 5 of 59 & hydroxychloroquine & developed color vision impairments \\
\hline
\end{tabular}

Figure 2: An example of Al generated results from text

For the Al to learn to perform this task, researchers at Evid Science employed Supervised Machine Learning. In this methodology, the researchers initially gave the Al very explicit examples of the type of output they want (similar in format to Figure 2 - they are sets of sentences and the associated structured results).

After developing a data set of thousands of such examples, from across varied articles in the literature, the machine learns to produce these types of output for brand new sentences. To be clear, the articles chosen for training are selected from multiple disease topics and with various interventions - not just focused on $\mathrm{HCQ}$. As the system improves, it can even be taught to correct mistakes, rather than having to start with fresh examples each time, thereby limiting the effort involved in refining its learning.

In previous work, we demonstrated a similar process to RMA, using the Evid Science Al to replicate the results from a Systematic Literature Review. ${ }^{9}$ Crucially, by leveraging Al we produced the results in six days, rather than the months it took to produce the original. Also, given the time between the original publication and Al-assisted version, 22 new relevant results had been published. We note, the current version of the Al used for this RMA is significantly more powerful than the version previously used for SLR replication.

The Evid Science clinical outcomes database used in this RMA is the result of running the Al over the entirety of the publicly (freely) available medical literature (PubMed). The current database has nearly 70,000,000 "facts" associated with results from articles which users can search and screen through.

Our RMA proceeds by searching and screening through this database, as we describe below. We note, the search itself (Step 1), leverages PubMed APIs, and therefore returns equivalent articles to PubMed.

Screening is then simplified, since the Al has processed the text into structured records that can be filtered and screened efficiently. For instance, we can simply filter to results associated with "toxicity" in the outcome (or other outcomes we care about). This is more efficient than manually reading each returned abstract, since one only screens articles in the filtered set.

After searching and screening, a user has the final data set for analysis. One can do many analyses directly within the Evid Science Web-based tool or export data to Excel and then analyze it with other programs (as we did). 
medRxiv preprint doi: https://doi.org/10.1101/2020.04.28.20083378; this version posted May 12, 2020. The copyright holder for this preprint (which was not certified by peer review) is the author/funder, who has granted medRxiv a license to display the preprint in perpetuity.

It is made available under a CC-BY-NC-ND 4.0 International license .

\section{Methods:}

In this section we describe our RMA process, focusing on eye issues and HCQ.

To start, we did a search for hydroxychloroquine on the Evid Science platform ${ }^{b}$, and filtered down to results where the outcome discussed major vision impairments (e.g., "maculopathy," "blind," "toxicity" etc.). This yielded 22 candidate articles (from a possible set of 5,010 articles related to $\mathrm{HCQ}$, of which 1,352 were identified as primary studies - e.g., trial or observational by our $\mathrm{Al}$ and therefore included as possible articles to process results from).

After screening, we were left with 11 papers for our RMA. (The 11 excluded articles were published before 2000 or focused on diagnosis of ocular issues). The search took less than 1 minute and the screening took 22 minutes (most of the work was selecting the papers and lightly cleaning the results to make the table of results easier to read.) The results from search and screening are in Table 1 below. This is the input to our meta-analysis computation.

Table 1: Results from Included papers

\begin{tabular}{|c|c|c|c|c|}
\hline Event & $\mathbf{N}$ & $\begin{array}{l}\text { Intervention } \\
\end{array}$ & $\begin{array}{c}\text { Outcome } \\
\end{array}$ & Citation \\
\hline 2 & 400 & $\begin{array}{l}\text { patients who were treated with } \\
\text { recommended dosages of the } \\
\text { drug for a mean of } 8.7 \text { years }\end{array}$ & $\begin{array}{l}\text { incidence of hydroxychloroquine- } \\
\text { related retinopathy }\end{array}$ & Mavrikakis I et al. (2003) ${ }^{10}$ \\
\hline 0 & 526 & hydroxychloroquine & $\begin{array}{l}\text { retinal toxicity was noted, during the } \\
\text { first } 6 \text { years of treatment }\end{array}$ & Mavrikakis I et al. $(2003)^{10}$ \\
\hline 46 & 845 & $\begin{array}{l}\text { chloroquine, } \\
\text { hydroxychloroquine, or both }\end{array}$ & $\begin{array}{l}\text { ophthalmological alterations, } \\
\text { confirmed by the ophthalmological } \\
\text { examination }\end{array}$ & Spinelli FR et al. (2018) $)^{11}$ \\
\hline 3 & 12 & $800 \mathrm{mg} /$ day hydroxychloroquine & $\begin{array}{l}\text { developed retinal toxicity with } \\
\text { scotomas in the Amsler grid and } \\
\text { Humphrey } 10-2 \text { automated perimetry, } \\
\text { as well as abnormal multifocal } \\
\text { electroretinography }\end{array}$ & Navajas EV et al. $(2015)^{12}$ \\
\hline 0 & 11 & long-term $\mathrm{HCQ}$ & $\begin{array}{l}\text { documented blindness, in all cases } \\
\text { attributed to a cause other than HCQ- } \\
\text { related ocular toxicity }\end{array}$ & Singh DK et al. (2019) ${ }^{13}$ \\
\hline 35 & 678 & hydroxychloroquine & had hydroxychloroquine toxicity & Chiu SY et al. (2018) \\
\hline 1 & 121 & hydroxychloroquine & prevalence of toxic retinopathy & Cabral RTS et al. $(2018)^{15}$ \\
\hline 18 & 59 & hydroxychloroquine & Retinal toxicity was detected & ESPANDAR G et al. (2016) ${ }^{16}$ \\
\hline 9 & 778 & antimalarial drugs & $\begin{array}{l}\text { suffered definite presence of } \\
\text { antimalarial retinopathy }\end{array}$ & Jover JA et al. $(2012)^{17}$ \\
\hline 11 & 36 & hydroxychloroquine & $\begin{array}{l}\text { had abnormal response densities in one } \\
\text { or both eyes }\end{array}$ & Maturi RK et al. $(2004)^{18}$ \\
\hline 3 & 26 & $\mathrm{HCQ}$ & $\begin{array}{l}\text { results from their electrophysiological } \\
\text { and clinical evaluation, toxicity (bull's- } \\
\text { eye maculopathy }\end{array}$ & Tzekov RT et al. $(2004)^{19}$ \\
\hline 4 & 93 & $\begin{array}{l}\text { chloroquine and } \\
\text { hydroxychloroquine therapy }\end{array}$ & $\begin{array}{l}\text { developed typical bull's eye } \\
\text { maculopathy }\end{array}$ & Neubauer AS et al. $(2003)^{20}$ \\
\hline
\end{tabular}

${ }^{b}$ In this study, we focus solely on PubMed abstracts, since those are freely available. 


\section{Results:}

We then meta-analyzed the above results, using a generalized linear mixed model (in the $\mathrm{R}$ programming language), as these are binary occurrences of having the eye issue. We chose the Random Effects model results, and back traced the effect to compute the expected number of observations of the issue per 100 observations. We report this number and the confidence interval (3.4\%; $95 \% \mathrm{Cl}$ : 1.11-9.96\%). The code for this analysis was already written, so plugging in the data (Table 1) and running it took roughly 2 minutes (export data to excel, rename and select columns to conform to R-code input, run the code).

The forest plot of the meta-analysis is shown in Figure 3 below. Clearly there is heterogeneity $\left(1^{2}\right.$ is $\left.97 \%\right)$, so these results warrant deeper inspection and cautious interpretation. The funnel plots of the results is shown in Figure 4.

\section{Study}

Mavrikakis I et al. (2003)

Mavrikakis I et al. (2003)

Spinelli FR et al. (2018)

Navajas EV et al. (2015)

Singh DK et al. (2019)

Chiu SY et al. (2018)

Cabral RTS et al. (2018)

ESPANDAR G et al. (2016)

Jover JA et al. (2012)

Maturi RK et al. (2004)

Tzekov RT et al. (2004)

Neubauer AS et al. (2003)

Fixed effect model

Random effects model

Heterogeneity: $I^{2}=97 \%, \tau^{2}=3.4448$

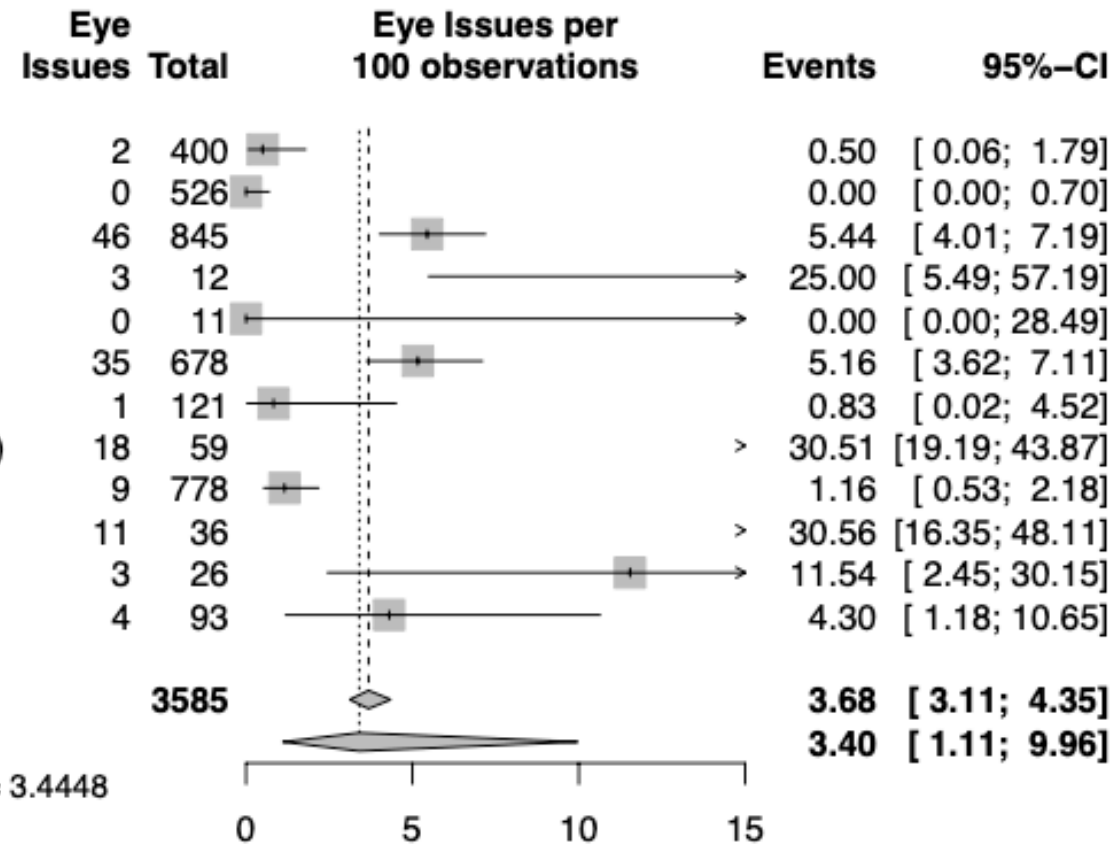

Figure 3: Forest plot for our RMA 
medRxiv preprint doi: https://doi.org/10.1101/2020.04.28.20083378; this version posted May 12, 2020. The copyright holder for this preprint (which was not certified by peer review) is the author/funder, who has granted medRxiv a license to display the preprint in perpetuity.

It is made available under a CC-BY-NC-ND 4.0 International license .

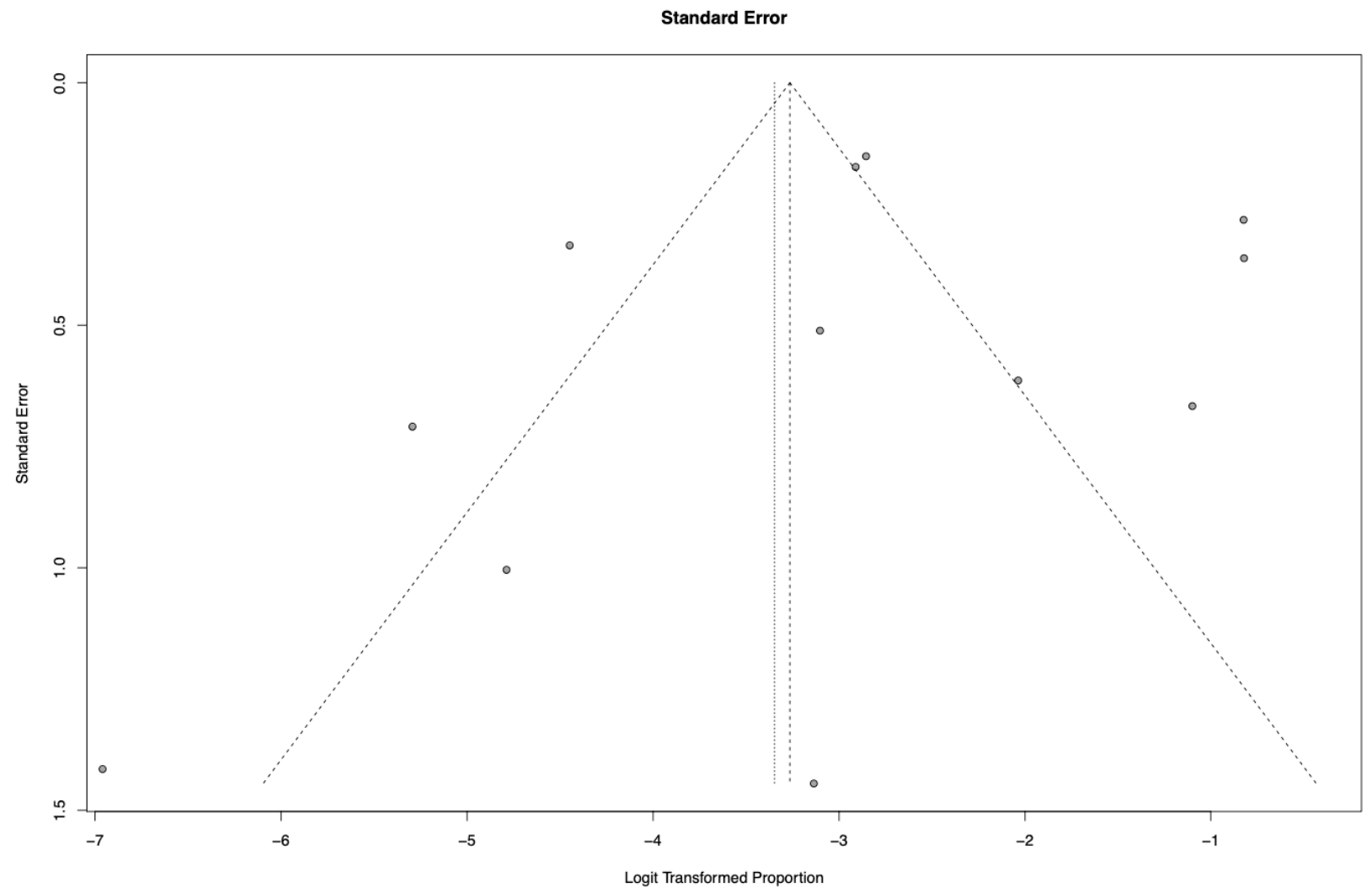

Figure 4: Funnel plot for our RMA

Each step of our RMA, its output and its timing are shown below in Figure 5 . This is RMA.

Search: "hydroxychloroquine" on Evid Science platform 1,352 articles (Trial or Observational study)

Time: 1 minute

Screen:

Inclusion: Filter articles whose outcome contains "toxicity," "maculopathy," "blind," etc.

Yields 22 articles (from 1,352)

Exclusion: Articles published before 2000; outcome focuses on diagnosis

Select results (in Evid Science platform) for meta-analysis

Yields 11 articles (from 22)

Time: 22 minutes

\section{Analysis:}

Export selected results

Manipulate exported spreadsheet to format expected $\mathrm{R}$ code

Load exported results into $\mathrm{R}$ code and generate meta-analysis results and figures

Time: 2 min

Figure 5: RMA for ocular toxicity associated with HCQ 
medRxiv preprint doi: https://doi.org/10.1101/2020.04.28.20083378; this version posted May 12, 2020. The copyright holder for this preprint (which was not certified by peer review) is the author/funder, who has granted medRxiv a license to display the preprint in perpetuity. It is made available under a CC-BY-NC-ND 4.0 International license .

\section{Conclusion:}

In this article we present a new framework for answering clinical questions when time is at a premium and can be traded off for data quality and depth. We call this a Rapid Meta-Analysis and we demonstrated its utility in answering a clinical question about a drug being proposed to treat COVID-19. While the results raise further questions that need to be considered (e.g., regarding the high heterogeneity), they do bring attention to an important clinical issue with the drug hydroxychloroquine. And importantly, the whole assessment was done in less than 30 minutes.

\section{References:}

1. Bastian H, Glasziou P, Chalmers I. Seventy-five trials and eleven systematic reviews a day: how will we ever keep up? PLoS Med. 2010 Sep 21;7(9):e1000326.

2. Loughlin EH, Rice JB, Wells HS, Rappaport I, Josepth AA. The treatment of Plasmodium falciparum malaria with a single dose antimalarial; a preliminary report of the use of hydroxychloroquine, 7-chloro-4(4-(N-ethyl-N-B-hydroxyethylamino)-1methylbutylamino)-quinoline diphosphate. Antibiot Chemother (Northfield). 1952 Apr;2(4):171-4

3. Sackett DL, Straus SE, Richardson WS, et al. Evidence-based medicine: how to practice and teach EBM. 2nd ed. Edinburgh: Churchill Livingstone, 2000

4. Higgins, JPT and Green, S, eds. Cochrane Handbook for Systematic Reviews of Interventions Version 5.1.0., 2011. Available from www.cochrane-handbook.org

5. Tsafnat G, Glasziou P, Choong MK, Dunn A, Galgani F, Coiera E. Systematic review automation technologies. Syst Rev. 2014 Jul 9;3:74.

6. Shojania KG, Sampson M, Ansari MT, Coucette S, Moher D. How quickly do systematic reviews go out of date? A survival analysis. Ann Intern Med. 2007 147: 224-233

7. Tsafnat, G., Glasziou, P., Choong, M.K. et al. Systematic review automation technologies. Syst Rev. 2014 3, 74.

8. Matthew Michelson, Automating Meta-Analyses of Randomized Clinical Trials: A First Look, In Proceedings of the AAAI Fall Symposium on Expanding the Boundaries of Health Informatics Using AI (HIAI), 2014

9. Michelson M, Ross M, and Minton S. AI2 LEVERAGING MACHINE-ASSISTANCE TO REPLICATE A SYSTEMATIC REVIEW. Value in Health. 2019 22: S34.

10. Mavrikakis I, Sfikakis PP, Mavrikakis E, Rougas K, Nikolaou A, Kostopoulos C, Mavrikakis $M$. The incidence of irreversible retinal toxicity in patients treated with hydroxychloroquine: a reappraisal. Ophthalmology. 2003 7, 1321-6.

11. Spinelli FR, Moscarelli E, Ceccarelli F, Miranda F, Perricone C, Truglia S, Garufi C, Massaro L, Morello F, Alessandri C, Valesini G, Conti F. Treating lupus patients with antimalarials: analysis of safety profile in a single-center cohort. Lupus. 2018 10, 1616-1623.

12. Navajas EV, Krema H, Hammoudi DS, Lipton JH, Simpson ER, Boyd S, Easterbrook M. Retinal toxicity of high-dose hydroxychloroquine in patients with chronic graft-versushost disease. Canadian journal of ophthalmology. Journal canadien d'ophtalmologie. 2015, 6, 442-50.

13. Singh DK, Muhieddine L, Einstadter D, Ballou S. Incidence of blindness in a population of rheumatic patients treated with hydroxychloroquine. Rheumatology advances in practice. 2019, 1, rkz009. 
medRxiv preprint doi: https://doi.org/10.1101/2020.04.28.20083378; this version posted May 12, 2020. The copyright holder for this preprint (which was not certified by peer review) is the author/funder, who has granted medRxiv a license to display the preprint in perpetuity. It is made available under a CC-BY-NC-ND 4.0 International license .

14. Chiu SY, Shaw JW, Luong TQ, Fong DS, Modjtahedi BS. Coding patterns used by ophthalmologists for hydroxychloroquine retinal toxicity. Clinical ophthalmology (Auckland, N.Z.). 2018, 2261-2265.

15. Cabral RTS, Klumb EM, Couto MINN, Carneiro S. Evaluation of toxic retinopathy caused by antimalarial medications with spectral domain optical coherence tomography. Arquivos brasileiros de oftalmologia, 2018.

16. Espandar G, Moghimi J, Ghorbani R, Pourazizi M, Seiri M, Khosravi S. Retinal Toxicity in Patients Treated With Hydroxychloroquine: A Cross-Sectional Study. Medical Hypothesis, Discovery and Innovation in Ophthalmology. 2016, 5(2), 41 - 46.

17. Jover JA, Leon L, Pato E, Loza E, Rosales Z, Matias MA, Mendez-Fernandez R, Díaz-Valle $\mathrm{D}$, Benitez-Del-Castillo JM, Abasolo L. Long-term use of antimalarial drugs in rheumatic diseases. Clinical and experimental rheumatology. 2012, 3, 380-7.

18. Maturi RK, Yu M, Weleber RG. Multifocal electroretinographic evaluation of long-term hydroxychloroquine users. Archives of ophthalmology (Chicago, III. : 1960). 2004, 7, 97381.

19. Tzekov RT, Serrato A, Marmor MF. ERG findings in patients using hydroxychloroquine. Documenta ophthalmologica. Advances in ophthalmology. 2004, 1, 87-97.

20. Neubauer AS, Samari-Kermani K, Schaller U, Welge-Lübetaen U, Rudolph G, Berninger T. Detecting chloroquine retinopathy: electro-oculogram versus colour vision. The British journal of ophthalmology. 2003, 7, 902-8. 